\title{
Environmental performance improvements and external stakeholder pressures in companies with certified Environmental Management System
}

\author{
Tiberio Daddi \\ Institute of Management \\ S. Anna School of Advanced Studies \\ Pisa, Italy \\ tiberio.daddi@sssup.it
}

Sara Tessitore

Institute of Management

S. Anna School of Advanced Studies

Pisa, Italy

sara.tessitore@sssup.it

\author{
Francesco Testa \\ Institute of Management \\ S. Anna School of Advanced Studies \\ Pisa, Italy \\ francesco.testa@sssup.it \\ Fabio Iraldo \\ Institute of Management \\ S. Anna School of Advanced Studies \\ Pisa, Italy \\ fabio.iraldo@sssup.it
}

Received: November 5, 2019. Revised: October 2, 2021. Accepted: October 27, 2021. Published: November $14,2021$.

\begin{abstract}
The relationship between environmental performance and Environmental Management Systems has been widely investigated by international researches. Despite this, our paper adds new perspectives to the current literature framework. First, it is focused on companies with an Environmental Management System registered according to EMAS Regulation, while many previous studies considered also ISO14001 certified companies. Second, to achieve the objectives of this paper, a wide sample of Italian companies was considered, and the results of a questionnaire survey filled out by 143 organizations are reported. In addition, this study points out the relationship between environmental performance and stakeholder pressures which have not been thoroughly investigated in previous papers. The results show that EMAS positively influences performance on some environmental aspects such as water consumption and emissions into the atmosphere, while this positive influence is not confirmed for other aspects. The Public Authorities represent the stakeholder identified by the survey as the main external pressure to improve environmental performance.
\end{abstract}

Keywords - Environmental Management System; environmental performance, stakeholder pressures

\section{INTRODUCTION}

Environmental Management Systems such as the systems implemented according to the ISO14001 standard or the European Regulation 1221/2009 (EMAS) establish the continuous improvement of environmental performance as a mandatory requirement. The registered companies must demonstrate improvements through specific planning and monitoring actions and, in the case of EMAS, must provide evidence of these improvements to the public through the yearly publication of an "Environmental Statement." Considering the relevance of this theme, many debates have been raised in the literature on how to monitor the real achievement of "continuous improvement." One of the main issues is related to the presence of two kinds of improvements: quantitative and intangible [8,10]. If the measurement of quantitative improvements can be considered easier, the intangible improvements are less discussed by authors.

This paper aims to present the results of a survey of a large number of Italian EMAS registered companies. The research was carried out by the authors in the year 2012 in the framework of the activities of an EU Life+ co-funded project called BRAVE ("Better Regulation Aimed to Valorising EMAS"). The article investigated both the effects of EMAS on the improvements of environmental performance and the pressures of external stakeholders as a leverage to stimulate these improvements.

The structure of the paper is the following: in the second section we describe the most important already existent studies related to the two topics of the article; in the third section we present the research questions, the research method and a description of the sample of the survey; in the fourth section we report and discuss the results achieved. In the final section we draw up the main conclusions, giving some directives on how further research should be developed. 


\section{LITERATURE FRAMEWORK}

\section{A. Environmental Management Systems and environmental performance}

In recent years the adoption and application of environmental management systems by businesses has inspired notable interest from scholars and researchers, especially in consideration of the increased popularity and spread of the European standards of EMAS and ISO 14001. Much evidence has been collected on the effects of EMAS on overall environmental performance. We report a few of the most recent and interesting data, according to the findings of studies that have used an econometric approach.

Examining a sample of 7,899 businesses that were a part of the group of production centers in the United States from 1995-2001, King et al. [1] found proof of the fact that the adoption of the EMS brought about improvements in environmental performance, measured as the logarithm of the weighted sum of the toxicity of the elements present in the Toxic Release Inventory. In another study, which used data from Japanese volunteer plants in an OECD poll, Arimura et al. [2] estimated the positive effects of ISO 14001 on the three improvements in environmental impact.

However, a small amount of contrasting evidence has been collected as well. The results of other studies show that the official EMSs (for example ISO 14001 and EMAS) do not substantially influence the environmental performance of companies [3,4]. One of the most significant empirical studies, which used a series of data from 37 cellulose and paper plants in Quebec from 1997-2003, did not find any significant proof of reduction of pollution since obtaining the ISO 14001 certification [5].

No quantitative proof exists yet on the long term impact of EMAS on performance because of a lack of temporal series data. However, researchers have attempted to evaluate if EMAS helps to promote environmental innovations. In a study of 1,277 German EMAS certified plants and 12 elaborations, Renning et al. (2003) [6] revealed that the environmental managers consider the execution of EMAS to be an important contributor to the introduction of environmental innovations, especially organizational ones. In a subsequent study related to the production managers in 588 German plants, carried out to evaluate the various integrated policy initiatives of products, Rennings et al. (2004) [7] found a weak but meaningful positive influence of ISO 14001 and EMAS on the environmental innovations of the products in question.

On the other hand, Hertin et al. (2004) [8] carried out an analysis of a chronological series of industrial companies on European production sites that apply various EMS policies. The principle result was that the connection between the EMSs of a company and its environmental performance (measured with indicators of eco-efficiency) is weak and ambiguous: the companies with official EMSs had the best results in particular indicators, but worse results in many others, and only a small number of correlations were statistically significant. Hertin et al. (2008), [9] in reporting the results of a research project called MEPI, carried out on the basis of the data of 274 companies and 400 production sites in six productive sectors of six countries of the EU, confirmed the weak connection between EMSs and environmental performance.

The study by Daddi et al. (2011) [10] analyzed the trends in environmental performance of a sample of 64 Italian companies of six different industrial sectors that possessed the EMAS registration for at least three years. In particular, the authors analyzed the influence of the EMAS registration on the improvement or worsening of environmental performance, and therefore the ability of this tool to move forward continuous improvement, which is a fundamental principle of the systems of certifications of environmental management. The data obtained indicate that in some cases EMAS causes effective improvement in environmental performance, even in short periods. Whether an EMS is useful or not can therefore depend significantly on various factors. One of these factors regards the fact that the company will need time to adopt the specificities of an EMS. This means that in order to be effective and achieve positive results in terms of environmental improvement, a company must set goals and plan management activities and technology investments. For example, Iraldo et al. (2009) [11], using data from more than 100 EMAS registered organizations, demonstrated that the number of years of application of the EMS has a positive effect on the level of environmental performance of the same organization. However, although this ratio is positive, the effect of the period of adoption of the EMS is not very high. This implies that the influence exerted over time by the EMS on the ability to improve the environmental performance is counterbalanced by other factors.

\section{B. External stakeholders as pressure to stimulate environmental improvement}

As postulated by the stakeholder theory, the pressure exerted by stakeholders significantly motivates companies to adopt different environmental practices (Sarkis et al., 2010) [22]. Taking Freeman's definition of stakeholders as a starting point, this means any group or individual who can affect or is affected by the achievement of the company's objectives (Freeman, 1984) [23]. Clarkson (1995) [24] identified two main groups of stakeholders according to their main interests: the main group of stakeholders are those without whose continued participation, the business could not survive. The secondary group of stakeholders have an interest in the company, but are not essential for its survival. Not all stakeholders, however, have the same influence: Mitchell et al. (1997) [25] argue that firms will take into account mainly the stakeholders that are considered authoritative and legitimate. In the literature, the analysis of the determining factors for the adoption of environmental practices, such as an environmental management system, focuses on the different sources of "stimulus" that guide the development of these tools, which will encourage the company to participate (Reed, 2008; Blanco et al., 2009) [26-27].

DiMaggio and Powell (1983), [28], for example, argue that the managerial decisions to adopt environmental initiatives can be affected by three institutional mechanisms: regulatory, coercive and mimetic. 
Regulatory pressures, such as customer requirements, lead companies to adapt in order to be perceived by the public as more legitimate. Furthermore, the community, environmental interest groups (Henriques \& Sadorsky, 1996) [29] and industry associations (Guler et al., 2002) [30] are able to exert this kind of pressure, thereby encouraging managers to adopt strategic actions oriented towards the supply chain, to increase their reputation and enhance their image on the market.

The coercive pressure can be imposed by different external stakeholders, depending on their authority. For example, by means of strict environmental regulations, governing bodies may force companies to adopt environmental practices (Delmas, 2002) [31]. This pressure comes from the threat of penalties and fines for non-compliance, or the request to publish information on the environmental impact of the company (Konar and Cohen, 1997). [32]

Henriques and Sadorsky (1999) [33] found that the pressure of regulatory stakeholders (eg. governments, trade associations) is higher in environmentally responsive firms, while the pressure of organizational stakeholders (eg. customers, suppliers, employees, shareholders) is higher in firms that are proactive in the environmental field.

Various studies focused on specific types of stakeholders found the positive influence of stakeholders including consumers (Dasguptaet al. 2000) [34], shareholders (Henriques and Sadorsky, 1996) [29], industry associations (Jimenez, 2007) [35], environmental interest groups (Henriques and Sadorsky, 1996) [29], public authorities (Alberini and Segerson, 2002) [36] in motivating environmental actions. Internal stakeholders also play a significant role in the adoption of environmental practices: employees, for example, are the source of competitive advantage of a company, and a successful environmental strategy requires their participation (Buzzelli, 1991) [37]. However, in order for a company to commit seriously to environmental issues, employees must be supported by the managerial leadership (Sarkis et al., 2010) [22].

In addition, managers can also be encouraged for strategic reasons (Head and Iraldo, 2010). The environmental management system, in fact, is able to provide a wide range of benefits, such as public recognition (Alberini and Segerson, 2002) [36], which allows companies to increase their share of the market or to ask higher prices for their products (Khanna, 2001) [38]. In an effort to increase resource productivity and reduce costs, an EMS can be adopted to rationalize the use of inputs (resources) such as energy and raw materials and at the same time, reduce output such as waste (Khanna \& Anton, 2002) [39]. Furthermore, the adoption of an EMS can improve the reputation and image of a company and, therefore, its relationships with customers, investors, local communities and other stakeholders (Biondi et al., 2000. Bansal and Roth, 2000; Khanna and Anton, 2002; Bansal and Hunter, 2003) [15-4039-41].

Research results have also demonstrated that the regulatory obligations and other external pressures can stimulate proactive behavior at the managerial level and bring about the application of an EMS (Darnall et al 2008, Gavronski et al,
2008) [42,43]. In a recent study by Darnall et al. (2008) [42], based on some aspects of the institutional theory and on a vision of business based on resources, they stated that institutional pressures (regulatory pressures, market and social pressures), resources and abilities (that is the commitment of the employees and environmental $R \& S$ ) encourage a more complete adoption of the EMS. Moreover, the overcoming of the informative asymmetries (King et al. 2005) [44] and the compliance with increasing regulatory requirements (Biondi et al. 2000) [15] represent further specific determining factors.

\section{RESEARCH QUESTION AND METHOD}

This paper aims to contribute to the literature debate in the field on the relationship between Environmental Management Systems and improvements in environmental performance. In addition, this paper investigated the opinions of the companies on who the main external stakeholders are, which stimulate the pursuing of the environmental improvements. This paper aims to respond to two main research questions:

a. Can an EMAS registered Environmental Management System lead to environmental improvements? Which environmental aspects are most significantly improved as an effect of EMAS?

b. Which are the main external stakeholders that stimulate EMAS companies to pursue environmental improvements?

\section{A. Method}

The methodological approach of the present study was designed to gather feedback and suggestions from EMAS organizations on the subject of administrative simplifications and about the results pursued through the implementation of an environmental management system. For this purpose, a survey was conducted involving Italian EMAS registered manufacturing companies.

To conduct the survey, the activities to be carried out were divided into the following categories:

- definition of the list of EMAS registered companies to which the questionnaire shall be submitted;

- $\quad$ preparation of the questionnaire;

- data collection;

- data analysis.

The first phase was dedicated to identifying the companies that would make up the statistical reference population, being the EMAS registered manufacturing companies operating in Italy, which were found through consulting the EMAS registry published on the ISPRA website and the registry of the European Commission, found at the website http://ec.europa.eu/environment/emas/register/. Through both of these consultations it was possible to obtain the information regarding the sector of the businesses considered. This allowed the researchers, for example, to delete public 
administrations from the list, since they do not benefit from any form of simplification or incentive. The choice to concentrate on the manufacturing sector (including the sector of waste and other environmental services) has two motivations. The first motivation is that the ability to define different measures of simplification is certainly larger since businesses in the manufacturing sector are subject to additional obligations arising from environmental legislation. The second is that the impact of environmental management on the internal organizational model is certainly greater than its impact on Public Administrations.

To achieve the objectives of the survey a questionnaire was prepared, consisting of 29 multiple choice questions.

In order to facilitate the completion of the questionnaire the online platform "Survey Monkey" was used, through which organizations inserted their answers to the questions themselves, without the need to produce paper documents.

The email addresses to which to send the questionnaire were obtained from the EMAS registry of the European Commission, which shows the details of the contact person for each organization, who is responsible for the environmental management system. The recipients of the survey were the representatives of 907 companies operating in a variety of industries and services, spread throughout all regions of Italy. The total population of EMAS registered companies in Italy is 1,134 . The first sending out of the email, with the instructions for filling out the questionnaire with the Survey Monkey web program, took place on July 20, 2012. The closing of the data collection was on September 25, 2012.

\section{B. Description of the sample}

The questionnaire was sent only to the EMAS companies and organizations operating in the various Italian regions, excluding Public Administration (PA code NACE 84). Overall, 143 organizations risponde, implying a survey response rate of $16 \%$. This rate is comparable with sample of other surveys used by studies published in academic journals (Paxson,1992) [45].The following table shows the national geographic distribution of EMAS registrations and for each region the percentage and number of organizations that participated in this study is shown.

TABLE I.

COMPANIES INVOLVED FOR EACH ITALIAN REGION

\begin{tabular}{|c|c|c|c|}
\hline \multirow{2}{*}{ Regions } & \multicolumn{3}{|c|}{ Data on companies } \\
\cline { 2 - 4 } & $\begin{array}{c}\text { EMAS } \\
\text { companies }\end{array}$ & $\begin{array}{c}\text { Companies } \\
\text { involved in } \\
\text { this study }\end{array}$ & $\%$ \\
\hline Abruzzi & 28 & 4 & $14 \%$ \\
\hline Basilicata & 13 & 0 & $0 \%$ \\
\hline Calabria & 7 & 0 & $0 \%$ \\
\hline Campania & 59 & 6 & $10 \%$ \\
\hline $\begin{array}{c}\text { Emilia } \\
\text { Romagna }\end{array}$ & 170 & 19 & $11 \%$ \\
\hline $\begin{array}{c}\text { Friuli Venezia } \\
\text { Giulia }\end{array}$ & 19 & 6 & $32 \%$ \\
\hline Lazio & 33 & 2 & $6 \%$ \\
\hline
\end{tabular}

\begin{tabular}{|c|c|c|c|}
\hline Liguria & 13 & 3 & $23 \%$ \\
\hline Lombardy & 137 & 23 & $17 \%$ \\
\hline Marche & 33 & 5 & $15 \%$ \\
\hline Molise & 10 & 0 & $0 \%$ \\
\hline Piedmont & 49 & 12 & $24 \%$ \\
\hline Puglia & 67 & 7 & $10 \%$ \\
\hline Sardinia & 16 & 1 & $6 \%$ \\
\hline Sicily & 24 & 4 & $17 \%$ \\
\hline Tuscany & 113 & 39 & $35 \%$ \\
\hline Trentino Alto & 37 & 3 & $8 \%$ \\
\hline Adige & 27 & 3 & $11 \%$ \\
\hline Umbria & 4 & 1 & $25 \%$ \\
\hline Valle d'Aosta & 48 & 5 & $10 \%$ \\
\hline Veneto & 907 & 143 & $16 \%$ \\
\hline Total & & &
\end{tabular}

$48 \%$ of the feedback comes from organizations of northern Italy, where EMAS registration is more common. $37 \%$ of the sample comes from central Italy, and only $7 \%$ comes from the south, where the certification is less common.

The manufacturing sectors in which this certification is most common are those of waste management, and the energy and food industries. Overall, the response rate was around $16 \%$ of registered enterprises. The response rate is particularly significant among organizations in the paper industry $(50 \%)$, and those in the transport (38\%) and textile sectors $(36 \%)$.

The following table introduces the sectorial distribution of EMAS registrations, and for each sector it presents the data on participation in this study.

TABLE II.

EMAS REGISTERED COMPANIES BY MANUFACTURING SECTOR AND RESPONSE RATE BY SECTOR

\begin{tabular}{|c|c|c|c|}
\hline \multirow[b]{2}{*}{ Manufacturing sector } & \multicolumn{3}{|c|}{ Data on companies } \\
\hline & $\begin{array}{c}\text { EMAS } \\
\text { companies }\end{array}$ & $\begin{array}{c}\text { Companies } \\
\text { involved in } \\
\text { this study }\end{array}$ & $\%$ \\
\hline $\begin{array}{c}\text { Agriculture, forestry, and } \\
\text { fishing }\end{array}$ & 21 & 2 & $10 \%$ \\
\hline Mining and quarrying & 15 & 1 & $7 \%$ \\
\hline Food industry & 95 & 10 & $11 \%$ \\
\hline $\begin{array}{l}\text { Textile industry and } \\
\text { clothing packaging }\end{array}$ & 14 & 5 & $36 \%$ \\
\hline $\begin{array}{c}\text { Leather production and } \\
\text { leather goods }\end{array}$ & 5 & 1 & $20 \%$ \\
\hline Wood and furniture industry & 13 & 2 & $15 \%$ \\
\hline $\begin{array}{c}\text { Production of paper and } \\
\text { paper products }\end{array}$ & 20 & 10 & $50 \%$ \\
\hline Printing & 2 & & \\
\hline Petrol products & 6 & 1 & $17 \%$ \\
\hline $\begin{array}{c}\text { Chemical and } \\
\text { pharmaceutical industry }\end{array}$ & 45 & 8 & $18 \%$ \\
\hline Rubber and plastic products & 25 & 4 & $16 \%$ \\
\hline Glass working & 29 & 1 & $3 \%$ \\
\hline Metal working & 50 & 13 & $26 \%$ \\
\hline Electronics & 27 & 1 & $4 \%$ \\
\hline
\end{tabular}




\begin{tabular}{|c|c|c|c|}
\hline Mechanical industry & 37 & 13 & $35 \%$ \\
\hline Other industries & 6 & 5 & $83 \%$ \\
\hline Energy & 128 & 12 & $9 \%$ \\
\hline Waste management & 175 & 33 & $19 \%$ \\
\hline Construction & 25 & 2 & $8 \%$ \\
\hline Trade & 13 & & \\
\hline Transport & 8 & 3 & $38 \%$ \\
\hline Hotels and restaurants & 34 & 2 & $6 \%$ \\
\hline Communication services & 13 & & \\
\hline Other activities and services & 71 & 12 & $17 \%$ \\
\hline Total & 877 & 141 & $16 \%$ \\
\hline
\end{tabular}

\section{RESULTS AND DISCUSSION}

\section{A. Environmental Management Systems and environmental performance}

The results of this study confirm the evidence reported in the relevant literature, being that the adoption of an environmental management system does not always determine a constant improvement of all aspects of environmental performance.

The survey carried out indicates, for example, that the environmental aspects that experienced performance improvements most frequently were emissions of pollutants into the atmosphere $(67 \%$ of those interviewed declared that they had obtained at least a "good" improvement), waste production $(69 \%)$, water consumption $(57 \%)$ and energy consumption $(60 \%)$. Improvements in terms of both efficiency in the use of raw materials and of auxiliary materials in production processes were shown to be quite limited.

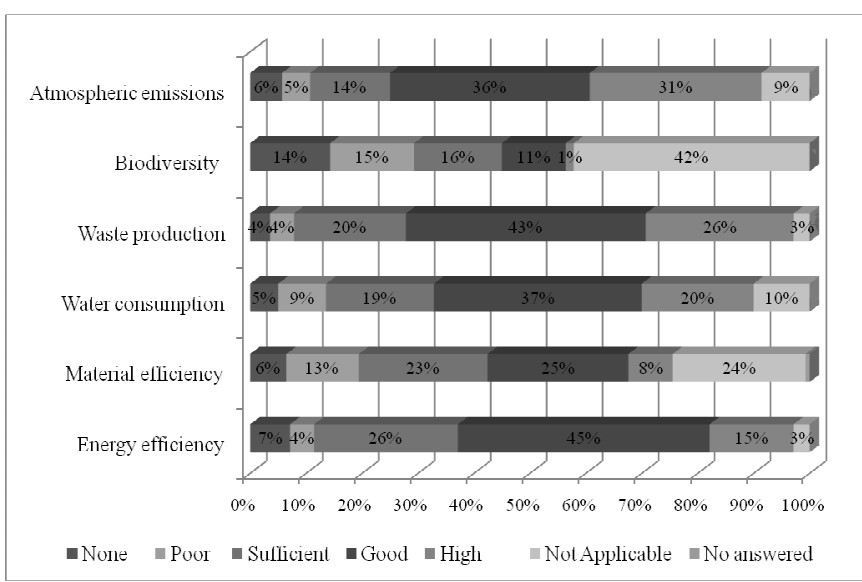

Fig. 1. Environmental improvements in environmental aspects in reference to unit of production since the date of implementation of the EMAS EMS

The following table shows the environmental aspects about which the respondents expressed a positive judgment in terms of improvements achieved (good or high). The manufacturing sector declared good and high improvements particularly with reference to waste production $(22 \%)$ and to energy efficiency and atmospheric emissions (21\% respectively). The sector of environmental services recorded an improvement in its performance in reference to both waste production and atmospheric emissions $(26 \%$ respectively), while the agricultural and food industry declares good and high performance with reference to energy efficiency and atmospheric emissions (25\% respectively). The sector that includes, on the other hand, various service fields records a higher level of improvement in energy efficiency and waste production ( $21 \%$ respectively).

TABLE III. PERCENTAGE OF ORGANIZATIONS THAT DECLARED THE ACHIEVEMENT OF AT LEAST “GOOD” IMPROVEMENTS

\begin{tabular}{|c|c|c|c|c|}
\hline \multirow{2}{*}{$\begin{array}{c}\text { Envrionmental } \\
\text { Aspect }\end{array}$} & Manufacturing & $\begin{array}{c}\text { Environmental } \\
\text { and energy } \\
\text { services }\end{array}$ & $\begin{array}{c}\text { Agriculture } \\
\text { and food }\end{array}$ & $\begin{array}{c}\text { Other } \\
\text { services }\end{array}$ \\
\cline { 2 - 5 } & $21 \%$ & $20 \%$ & $25 \%$ & $21 \%$ \\
\hline $\begin{array}{c}\text { Energy } \\
\text { efficiency }\end{array}$ & $12 \%$ & $7 \%$ & $13 \%$ & $13 \%$ \\
\hline $\begin{array}{c}\text { Material } \\
\text { efficiency }\end{array}$ & $20 \%$ & $18 \%$ & $22 \%$ & $18 \%$ \\
\hline $\begin{array}{c}\text { Water } \\
\text { consumption }\end{array}$ & $22 \%$ & $26 \%$ & $16 \%$ & $21 \%$ \\
\hline $\begin{array}{c}\text { Waste } \\
\text { production }\end{array}$ & $3 \%$ & $4 \%$ & $0 \%$ & $13 \%$ \\
\hline $\begin{array}{c}\text { Biodiversity } \\
\text { Atmospheric } \\
\text { emissions }\end{array}$ & $21 \%$ & $26 \%$ & $25 \%$ & $15 \%$ \\
\hline
\end{tabular}

The results shown above correlate to a series of variables of controls listed below:

(1) Number of years since the registration was obtained (2) age of the organization; (3) number of employees; (4) position in the supply chain; (5) geographical dimension of the market; (6) number of competitors; (7) price as a competitive factor; (8) quality as a competitive factor; (9) reputation as a competitive factor; (10) relationships with suppliers as a competitive factor; (11) economic performance.

In the following table the data obtained through elaboration with repect to these control variables are reported.

TABLE IV. CORRELATION MATRIX OF ENVIRONMENTAL PERFORMANCE AND CONTROL VARIABLES (FROM VARIABLE 1 TO 5)

\begin{tabular}{|c|c|c|c|c|c|}
\hline \multirow{2}{*}{ Aspects } & \multicolumn{5}{|c|}{ Control variables } \\
\cline { 2 - 6 } & $(1)$ & $(2)$ & $(3)$ & (4) & $(5)$ \\
\hline $\begin{array}{c}\text { Energy } \\
\text { efficiency }\end{array}$ & .017 & .012 & .002 & .041 & .074 \\
\hline $\begin{array}{c}\text { Material } \\
\text { efficiency }\end{array}$ & -.003 & .039 & .153 & .004 & .116 \\
\hline $\begin{array}{c}\text { Water } \\
\text { consumption }\end{array}$ &. $\mathbf{1 6 8 *}$ & .052 & $\mathbf{. 1 7 3 * *}$ & .047 & $\mathbf{. 1 7 6 * *}$ \\
\hline $\begin{array}{c}\text { Waste } \\
\text { production }\end{array}$ & .033 & -.007 & .072 & .094 & .064 \\
\hline
\end{tabular}




\begin{tabular}{|c|c|c|c|c|c|}
\hline Biodiversity & -.167 & $-.249 * *$ & -.132 & .115 & -.116 \\
\hline $\begin{array}{c}\text { Atmospheric } \\
\text { emissions }\end{array}$ & .106 & -.077 & .050 & .009 & -.016 \\
\hline
\end{tabular}

TABLE V. CORRELATION MATRIX OF ENVIRONMENTAL PERFORMANCE AND CONTROL VARIABLES (FROM VARIABLE 6 TO 11)

\begin{tabular}{|c|c|c|c|c|c|c|}
\hline \multirow{2}{*}{ Aspects } & \multicolumn{5}{|c|}{ Control variables } \\
\cline { 2 - 7 } & $\mathbf{( 6 )}$ & $\mathbf{( 7 )}$ & $\mathbf{( 8 )}$ & $\mathbf{( 9 )}$ & $\mathbf{( 1 0 )}$ & $\mathbf{( 1 1 )}$ \\
\hline $\begin{array}{c}\text { Energy } \\
\text { efficiency }\end{array}$ & .076 & -.122 & $\mathbf{. 2 0 1 * *}$ & .099 & .137 & .042 \\
\hline $\begin{array}{c}\text { Material } \\
\text { efficiency }\end{array}$ & .108 & -.080 & $\mathbf{. 1 7 3 *}$ & $\mathbf{. 1 7 2 *}$ & .111 & -.024 \\
\hline $\begin{array}{c}\text { Water } \\
\text { consumption }\end{array}$ & .099 & $\mathbf{- 0 . 1 6 7 *}$ & .065 & .012 & .046 & -.010 \\
\hline $\begin{array}{c}\text { Waste } \\
\text { production }\end{array}$ & .070 & -0.041 & .047 & .131 & $\mathbf{. 1 9 6} * *$ & -.068 \\
\hline \begin{tabular}{c} 
Biodiversity \\
\hline $\begin{array}{c}\text { Atmospheric } \\
\text { emissions }\end{array}$
\end{tabular} & .139 & -0.131 & $\mathbf{. 2 2 2} * *$ & $.212 *$ & .146 & -.032 \\
\hline
\end{tabular}

$* * * ; * * ; *$ The correlation is meaningful for $99 \% ; 95 \% ; 90 \%$ respectively.

The analysis of the interdependencies between improved environmental performance and some control variables showed some statistically significant relationships. For example, it is shown that companies who claim that product quality is a competitive factor of strategic importance also found positive improvements on various environmental aspects such as energy and material efficiency, biodiversity and atmospheric emissions. Companies with competitive strategies that focus on relationships along the supply chain also declared that they had made significant improvements in terms of reducing waste production and the quality of their emissions into the atmosphere. As for the negative reports, it emerges that the older companies state that they had more difficulty in achieving improvements in the impact of their production on biodiversity, while companies that base their competitive strategy on the price of their products achieved little improvement in the use of water resources.

\section{B. Results: stakeholders as pressure to stimulate environmental improvement}

In order to evaluate the role of external stakeholders in the actions of EMAS registered businesses, the interviewees were asked about the level of influence of a few stakeholders on their adoption of actions for environmental improvement.

The results of the survey confirmed a relevant role of the public authority in stimulating actions for improvement. That pressure must be, in our opinion, interpreted as having two meanings: on the one hand, the pressure inherent in public bodies at the local level can stimulate companies, for example, to participate in local voluntary initiatives oriented towards the adoption of a certain practice or technology. On the other hand, the constantly high attention and severity of the legislator through instruments of command and control is indicated.

The results show that this pressure is felt more strongly by young businesses and by those that do not make the quality of their products or their relationships with suppliers a key element of their competitive strategy.

The pressure by the stakeholders is perceived as very important by almost one out of four businesses, while $18 \%$ consider the influence of the commercial purchasers relevant for the adoption of actions for environmental improvement, in particular in companies that make their reputation a central element of their strategy.

The stakeholders that provide the least amount of pressure leading to actions for environmental improvement were shown to be labor unions and banks. While for the former this result is rather expected, the survey shows that financial institutions still do not consider environmental risk to be a relevant element to the financial risk analysis of an organization, and they do not, in fact, have interest in stimulating improvements in the environmental performance of businesses.

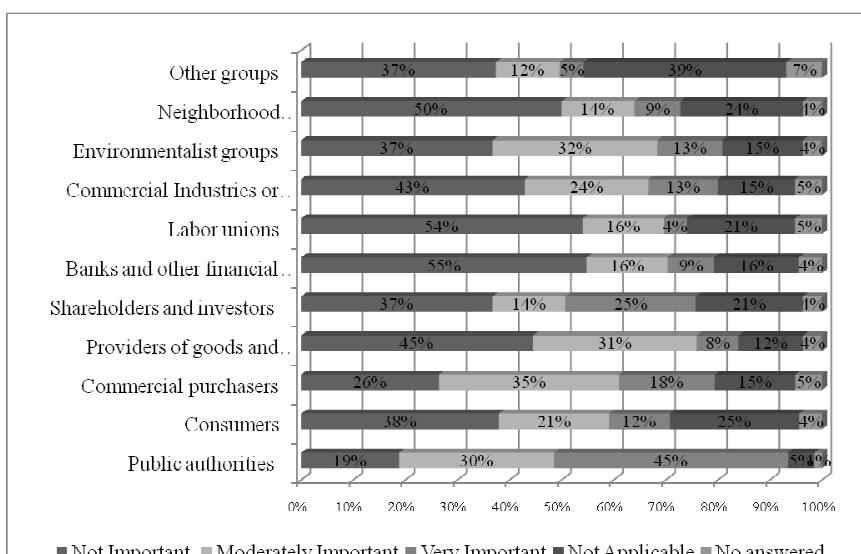

Fig. 2. Stakeholders that influenced the choice of the organization to take actions for environmental improvement

Similarly to what was done for the table on environmental performance, the table below shows the results of the study of the correlations between stakeholders and the influence of the control variables adopted.

TABLE VI. CORRELATION MATRIX OF THE INFLUENCE OF STAKEHOLDERS AND CONTROL VARIABLES (FROM VARIABLES 1 TO 5)

\begin{tabular}{|c|c|c|c|c|c|}
\hline \multirow{2}{*}{ Stakeholder } & \multicolumn{5}{|c|}{ Control variables } \\
\cline { 2 - 6 } & $(\mathbf{1})$ & $\mathbf{( 2 )}$ & $\mathbf{( 3 )}$ & $\mathbf{( 4 )}$ & $\mathbf{( 5 )}$ \\
\hline Public authorities & -.066 & $-.198^{* *}$ & $\mathbf{- . 1 3 6}$ & -.037 & $-.165^{*}$ \\
\hline Consumers & $.229 * *$ & .047 & $\mathbf{. 0 2 5}$ & $\begin{array}{c}.297 * * \\
*\end{array}$ & -.078 \\
\hline $\begin{array}{c}\text { Commercial } \\
\text { purchasers }\end{array}$ & .116 & -.005 & .018 & .057 & $.182 *$ \\
\hline $\begin{array}{c}\text { Providers of goods } \\
\text { and services }\end{array}$ & $\mathbf{- . 0 1 8}$ & $\mathbf{- . 1 9 4 * *}$ & $\mathbf{- . 2 0 3 * *}$ & $\mathbf{- . 0 2 9}$ & -.112 \\
\hline $\begin{array}{c}\text { Shareholders and } \\
\text { investors }\end{array}$ & $\mathbf{. 1 6 5}$ & .008 & .059 & .072 & .087 \\
\hline $\begin{array}{c}\text { Banks and other } \\
\text { financial institutions }\end{array}$ & $\mathbf{. 1 8 5 *}$ & .000 &. $\mathbf{1 7 6 *}$ & -.043 & .114 \\
\hline
\end{tabular}




\begin{tabular}{|c|c|c|c|c|c|}
\hline Labor unions & $\mathbf{. 1 9 1 *}$ & -.004 & $.197 *$ & .072 & .133 \\
\hline $\begin{array}{c}\text { Commercial } \\
\text { Industries or } \\
\text { Associations }\end{array}$ & .121 & -.036 & -.015 & -.088 & -.039 \\
\hline $\begin{array}{c}\text { Environmentalist } \\
\text { groups }\end{array}$ & .022 & -.102 & -.097 & -.130 & -.053 \\
\hline $\begin{array}{c}\text { Neighborhood } \\
\text { groups/community }\end{array}$ & .095 & .020 & .035 & -.072 & -.075 \\
\hline
\end{tabular}

TABLE VII. CORRELATION MATRIX OF THE INFLUENCE OF STAKEHOLDERS AND CONTROL VARIABLES (FROM VARIABLE 6 TO 11)

\begin{tabular}{|c|c|c|c|c|c|c|}
\hline \multirow{2}{*}{ Stakeholder } & \multicolumn{5}{|c|}{ Control variables } \\
\cline { 2 - 7 } & $\mathbf{( 6 )}$ & $\mathbf{( 7 )}$ & $\mathbf{( 8 )}$ & $\mathbf{( 9 )}$ & $\mathbf{( 1 0 )}$ & $\mathbf{( 1 1 )}$ \\
\hline $\begin{array}{c}\text { Public } \\
\text { authorities }\end{array}$ & .102 & $\mathbf{. 0 0 3}$ & $\begin{array}{c}- \\
.248^{*} \\
* *\end{array}$ & -.044 & $\begin{array}{c}- \\
.233^{*} \\
* *\end{array}$ & -.015 \\
\hline Consumers & -.158 & -.132 & -.010 & .106 & -.043 & $\mathbf{- . 1 9 3 *}$ \\
\hline $\begin{array}{c}\text { Commercial } \\
\text { purchasers }\end{array}$ & .074 & $\mathbf{. 0 6 3}$ & .102 & $\begin{array}{c}.198^{*} \\
*\end{array}$ & .097 & -.142 \\
\hline $\begin{array}{c}\text { Providers of } \\
\text { goods and } \\
\text { services }\end{array}$ & -.088 & -.069 & .063 & $.176^{*}$ & $\begin{array}{c}.288^{*} \\
* *\end{array}$ & -.127 \\
\hline $\begin{array}{c}\text { Shareholders } \\
\text { and investors }\end{array}$ & -.063 & -.119 & $\mathbf{- . 0 1 4}$ & -.031 & $\mathbf{- . 0 7 7}$ & -.044 \\
\hline $\begin{array}{c}\text { Banks and other } \\
\text { financial } \\
\text { institutions }\end{array}$ & .082 & $.164 *$ & .078 & .049 & -.060 & .030 \\
\hline Labor unions & -.100 & .002 & .158 & .072 & .108 & $-.188^{*}$ \\
\hline $\begin{array}{c}\text { Commercial } \\
\text { Industries or } \\
\text { Associations }\end{array}$ & .017 & .048 & .068 & -.041 & .132 & -.124 \\
\hline $\begin{array}{c}\text { Environmentali } \\
\text { st groups }\end{array}$ & .101 & -.058 & -.055 & .062 & .010 & -.109 \\
\hline $\begin{array}{c}\text { Neighborhood } \\
\text { groups/commun } \\
\text { ity }\end{array}$ & -.067 & -.003 & .082 & .095 & .006 & .007 \\
\hline
\end{tabular}

$* * * ; * ; *$ The correlation is meaningful for $99 \% ; 95 \% ; 90 \%$ respectively

The analysis of the interdependencies between improving the influence of external stakeholders and some control variables showed some statistically significant relationships. For example, it emerged that younger companies experience greater pressure from suppliers and public authorities with respect to companies that have already been operating for several years. Companies of larger size appear to be more responsive to requests from financial institutions and trade unions, while companies that produce for the retail market are obviously more sensitive to pressures from consumers. In addition, companies with competitive strategies that focus on relationships along the supply chain and on the quality of their products are less influenced by public authorities, but make significant considerations for their suppliers.

\section{CONCLUSIONS}

The results on the relationship between EMSs and environmental improvements confirm the findings of previous studies included in the literature. We can't affirm that this relationship is strictly positive or negative; on the contrary it presents ambiguous results. EMAS has positive influences on certain environmental aspects such as air emissions, water consumption and waste production. This positive influence is not clearly confirmed for energy consumption. The improvements linked with water consumption and waste production can be justified by the monitoring requirements imposed by the EMS. According to these requirements the companies must collect and analyse several data and performance indicators, which are not always verified before the implementation of the EMS. This activity allows them to identify possible improvement actions (e.g. the data can point out opportunities to reduce or reuse waste, or the presence of leaks in the water supply system) which were not previously identifiable. On the contrary, taking into account the economic relevance of energy consumption, the low effect on the improvement of this aspect can be related to the few improvement opportunities identified after EMAS registration. Usually the companies, before the implementation of the EMS, have already taken actions to increase the energy efficiency of the plant in order to achieve economic savings. For this reason, after obtaining EMAS certification, improvements are harder to achieve.

The results obtained regarding the pressures exerted by the external stakeholders were generally predictable. The Public Authorities were shown to represent the main external pressure, and this result can be linked with the "nature" of EMAS registration. EMAS, unlike ISO14001, is an environmental policy tool based on a public system. It was established through public Regulation and its functioning is based on a national public Committee (EMAS Committee). For this reason the organizations that decide to move toward EMAS registration identify the pressures of Public Authorities as the main driver for EMAS adoption.

We invite scholars to further develop this research in two main directions. First, it could be interesting to investigate the influence of EMAS on the improvement of intangible aspects of performance, such as a better capacity to manage environmental emergencies or a better capacity to manage legal compliance. Second, the part of this study related to the external pressures could be elaborated by investigating the main internal pressures that drive the implementation of EMSs

\section{REFERENCES}

[1] A .King, M . Lenox, A. Terlaak, "The strategic use of decentralized institutions: Exploring certification with the ISO 14001 management standard", Academy of Management Journal, vol.48, 2005, pp. 10911106.

[2] T.Arimura, A. Hibiki, H. Katayama "Is a voluntary approach an effective environmental policy instrument? A case for environmental management systems", Journal of Environmental Economics and Management vol. 55, 2008, pp. 281-295.

[3] K.Dahlstrom, C. Howes, O. Leinster, J.Skea "Environmental management systems and company performance: assessing the case for extending risk-based regulation", European Environment, vol. 13, 2003, pp.187-203.

[4] R.N.L. Andrews, D.Amaral, S. Keiner, N.Darnall, D.R. Gallagher, JD Edwards, A Hutson, C. D’Amore, L. Sun, Y. Zhang. "Environmental management systems: do they improve performance?" Project Final Report for US EPA, Office of Water and Office of Policy, Economics and Innovation, 2003. Available form http://www.cota.vt.edu/ 
[5] P.Barla "ISO 14001 certification and environmental performance in Quebec's pulp and paper industry", Journal of Environmental Economics and Management vol. 53, 200, pp. 291-306

[6] K. Rennings, A. Ziegler, K.Ankele, S.Hoffman J, Nill "The influence of the EU Environmental Management Management and Audit Scheme on Environmental Innovations and Competitiveness in Germany: An Analysis on the Basis of Case Studies and a Large-Scale Survey". ZEW Discussion Paper No. 03-14, 2003 unpublished.

[7] K. Rennings, A. Ziegler, K. Rehfeld, "Integrated Product Policy and Environmental Product Innovations: An Empirical Analysis". ZEW Discussion papers 2004 unpublished.

[8] J.Hertin, Berkhout, F. Wagner, M. Tyteca,: “Are 'soft' policy instruments effective? The link between environmental management systems and the environmental performance of companies". SPRU Electronic Working Papers Series 2004.

[9] J.Hertin, F. Berkhout., M. Wagner and D. Tyteca, "Are EMS environmentally effective? The link between environmental management systems and environmental performance in European companies". Journal of Environmental Planning and Management, vol. 51 (2), 2008, pp. 259-283

[10] T. Daddi, M.Magistrelli, M.Frey, F.Iraldo. "Do Environmental Management Systems improve environmental performance? Empirical evidence from Italian companies". Environment,Development and Sustainability, 2011, pp. 845-862.

[11] F.Iraldo, F Testa and M.Frey "Is an environmental management system able to influence environmental and competitive performance? The case of the eco-management and audit scheme (EMAS) in the European union”, Journal of Cleaner Production vol. 17, 2009, pp. 1444-1452

[12] Milieu Ltd and Risk and Policy Analysis Ltd, "Study on the Costs and Benefits of EMAS to Registered Organisations". Final Report for DG Environment of the European Commission under Study Contract No. 07.0307/2008/517800/ETU/G.2, 2009.

[13] ISO, ISO, "The Global Use of Environmental Management System by Small and Medium Enterprises: Executive Report" by ISO/TC207/SC1/Strategic SME Group, ISO, Geneva2005.

[14] J. Hamschmidt, T. Dyllick,." ISO 14001: profitable? Yes! But is it ecoeffective?", Greener Management International, vol. 34, 2001, pp. 43-54

[15] V. Biondi, M.Frey and F. Iraldo, "Environmental Management Systems and SMEs", Greener Management International, vol. Spring, 2000, pp. $55-79$.

[16] Cesqa \& Sincert, "Indagine sulla certificazione ambientale secondo la norma UNI EN ISO 14001; risultati indagine" Triveneto, 2002.

[17] R. Hillary, "Environmental management systems and the smaller enterprise", Journal of Cleaner Production 12, 2004, pp. 763-777

[18] R.Hillary, (1999). "Evaluation of study reports on the barriers, opportunities and drivers for small and medium sized enterprises - the adoption" Journal of Cleaner Production vol. 7, 1999, pp.1-11.

[19] M. Zackrisson, M. Enroth, A. Widing. "Environmental management systems - paper tiger or powerful tool. Assessment of the environmental and economic effectiveness of ISO 14001 and EMAS" Industrial Research Institutes in Sweden IVF Research Publication 00828, Stockholm, 2000

[20] IEFE Bocconi, Adelphi Consult, IOEW, SPRU, Valor \& Tinge, "EVER: Evaluation of eco-label and EMAS for their Revision - Research findings", Final report to the European Commission - Part I-II, DG Environment European Community; Brussels 2006. available from www.europa.eu.int/comm/environment/emas.

[21] R..MacLean. "Getting the most from your EMS", Manager's Notebook, Environment Proctecion March. Available from http://eponline.com/Articles/2004/03/01/Environmental-ManagementSystems--Part-2.aspx?Page=1

[22] J. Sarkis, P.Gonzalez-Torre, B. Adenso-Diaz. "Stakeholder pressure and the adoption of environmental practices: The mediating effect of training". Journal of Operations Management, vol. 28, 2010 163-176

[23] R. E.Freeman, "Strategic management : A stakeholder approach. Pitman, Boston, 1984
[24] M.B.E Clarkson, "A Stakeholder Framework for Analyzing and Evaluating Corporate Social Performance". Academy of Management Review, vol. 29, 1995, pp. 92-117

[25] R. Mitchell, B. Agle, D. Wood. "Toward a Theory of Stakeholder Identification and Salience: Defining the Principle of Who and What Really Counts”. Academy Management Review, vol. 22, 1997, pp.853886.

[26] M.S. Reed, "Stakeholder participation for environmental management: A literature review", Biological Conservation, vol. 141, 2008, pp. 24172431

[27] E. Blanco, J. Lozano, J. Rey-Maquieira, "A dynamic approach to voluntary environmental contributions in tourism", Ecological Economics, vol. 69, 2009, pp.104-114

[28] P.J. Di Maggio, W.W. Powell, "The iron cage revisited: institutional isomorphism and collective rationality in organizational fields". American Sociological Review, vol. 48, 1983, pp.147-160.

[29] I.Henriques, P. Sadorsky, "The determinants of an environmentally responsive firm: an empirical approach", Journal of Environmental Economics and Management, vol. 30, 1996, pp. 381-395.

[30] I. Guler, M.F Guillen, J.M MacPherson, "Global competition, institutions, and the diffusion of organizational practices: the international spread of the ISO 9000 quality certificates", Administrative Science Quarterly, vol. 47, 2002, pp. 507-531.

[31] M. Delmas, A. Terlaak,. "Regulatory Commitment to Negotiated Agreements: Evidence from the United States, Germany, The Netherlands, and France". Journal of Comparative Policy Analysis, vol. 4, 2002, pp. 5-29

[32] S. Konar, M.A.Cohen. "Information as regulation: the effect of community right to know laws on toxic emissions". Journal of Environmental Economics and Management, vol. 32, 1997, pp. 109124

[33] I.Henriques, P. Sadorsky, "The relationship between environmental commitment and managerial perceptions of stakeholder importance". Academy of Management Journal,vol. 42, 1999, pp. 87-99

[34] S. Dasgupta, H. Hettige, D.Wheeler. "What improves environmental performance? Evidence from Mexican industry". Journal of Environmental Economics and Management, vol. 39, 2000 pp. 39-66.

[35] O. Jimenez, "Voluntary agreements in environmental policy: an empirical evaluation for the Chilean case". Journal of Cleaner Production., vol.15, 2007, pp. 620-637

[36] A. Alberini, K. Segerson, "Assessing Voluntary Programs to Improve Environmental Quality". Environmental and Resource Economics, vol. 22, 2002, pp. 157-184

[37] D.T. Buzzelli, "Time to structure an environmental policy strategy". Journal of Business Strategy, vol. 12, 1991, pp. 7-20.

[38] M.Khanna, "Non-mandatory approach to environmental protection", Journal of Economic Survey, vol. 15, 2001, pp. 291-324

[39] M. Khanna, W.R.Q. Anton, "Corporate environmental management: regulatory and market-based incentives". Land Economics 78, 2002, pp. $539-558$

[40] P. Bansal, K. Roth, "Why companies go green: A model of ecological responsiveness", Academy of Management Journal, vol. 43, 2000, pp. 717-736

[41] P. Bansal, T. Hunter, "Strategic explanations for the early adoption of ISO 14001", Journal of Business Ethics vol.46, 2003, pp. 289-299

[42] N. Darnall, G. Jason Jolley, R. Handfield, "Environmental Management Systems and Green Supply Chain Management: Complements for Sustainability?" Business Strategy and the Environment, vol. 18, 2008a, pp. $30-45$

[43] I.Gavronski, G. Ferrer, E.L Paiva, "ISO 14001 certification in Brazil: motivations and benefits", Journal of Cleaner Production, vol.16, 2008, pp. $87-94$

[44] A. King, M. Lenox, A. Terlaak, "The strategic use of decentralized institutions: Exploring certification with the ISO 14001 management standard", Academy of Management Journal, vol. 48, 2005, pp. 10911106.

[45] M.C. Paxson, "Response Rates for 183 studie"s. Working Paper Washington State University, Washington State University, 1992.

Creative Commons Attribution License 4.0 (Attribution 4.0 International, CC BY 4.0)

This article is published under the terms of the Creative Commons Attribution License 4.0 https://creativecommons.org/licenses/by/4.0/deed.en_US 